\title{
Relative development of tissues, commercial meat cuts and live weight components in Saanen goats ${ }^{1}$
}

\section{Enrique Alejandro Yáñez ${ }^{2}$, Kleber Tomás de Resende ${ }^{3}$, Ângela Cristina Dias Ferreira ${ }^{4}$, José Morais Pereira Filho ${ }^{5}$, Ariosvaldo Nunes de Medeiros ${ }^{6}$, Izabelle Auxiliadora Molina de Almeida Teixeira ${ }^{3}$}

1 Projeto financiado junto à FAPESP.

2 Depto. de Producción Animal, Facultad de Ciencias Veterinarias, UNNE, Corrientes. Sargento Cabral 2139, Corrientes, Argentina. CP: 3400.

${ }^{3}$ Depto. de Zootecnia, Faculdade de Ciências Agrárias e Veterinárias, Unesp, Jaboticabal. Rod. P.D. Castellane Km 5, Jaboticabal, SP. CEP: $14884-900$.

${ }^{4}$ Depto. de Zootecnia, Unoeste-Presidente Prudente, SP.

${ }^{5}$ Depto. de Medicina Veterinaria da Universidade Federal de Campina Grande, Patos, PB.

${ }^{6}$ Depto. de Zootecnia do Centro de Ciências Agrárias, UFPB, Areia, PB.

ABSTRACT - With the objective of evaluating the relative development of live weight (LW) components, commercial meat cuts and carcass tissues, 40 Saanen male kids were used. These animals were slaughtered when they reached 5.0, 12.5, 20.0, 27.5 and $35.0 \mathrm{~kg}$ of LW. The carcass was sectioned as follows: shoulder, neck, $1^{\text {st }}$ to $5^{\text {th }}$ rip, $6^{\text {th }}$ to $13^{\text {th }}$ rip, brisket, chump and leg. The leg was dissected into bones, muscle and fat. An allometric equation was used $\mathrm{Y}=\mathrm{aX} \mathrm{X}^{\mathrm{b}}$ for relative development estimation. Osseous tissue showed a precocious growth, intermediary muscle and adipose tissues had a late growth, being the subcutaneous fat the latest. All commercial meat cuts showed an isogonic allometric coefficient, with exception for the $6^{\text {th }}$ to $13^{\text {th }}$ rip, and brisket. Carcass development and non-carcass components followed the empty body weight. Goats with $35 \mathrm{~kg}$ of LW showed adequate muscle proportion and muscle:bone ratio, but higher fat proportion than kids slaughtered at $20 \mathrm{~kg}$ of LW.

Key Words: allometric, carcass development, commercial yield, fat, kids, muscle

\section{Desenvolvimento relativo dos tecidos, cortes comerciais e dos componentes do peso vivo de cabritos Saanen}

\footnotetext{
RESUMO - Objetivando avaliar o desenvolvimento relativo dos componentes do peso vivo (PV), dos cortes comerciais e dos tecidos da carcaça, utilizaram-se 40 cabritos Saanen. Os animais foram abatidos ao atingir 5,0; 12,5; 20,0; 27,5 e 35,0 kg de PV e a carcaça foi seccionada em paleta, pescoço, $1^{\underline{a}}$ a $5^{\underline{a}}$ costelas, 6 $6^{\mathrm{a}}$ a $13^{\underline{a}}$ costelas, peito/fralda, lombo e perna. A perna foi dissecada em ossos, músculos e gordura. Utilizou-se a equação alométrica $\mathrm{Y}=\mathrm{a} \mathrm{X}^{\mathrm{b}}$ para estimar o desenvolvimento relativo. O crescimento do tecido ósseo foi precoce, o do tecido muscular intermediário e o da gordura crescimento tardio, uma vez que a gordura subcutânea é depositada mais tardiamente. Os cortes comerciais apresentaram

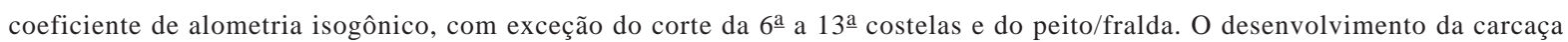
e dos não-componentes da carcaça acompanhou o peso de corpo vazio. Cabritos com $35 \mathrm{~kg}$ de PV possuem proporção de músculos e relação músculo:osso adequadas, mas apresentam proporção de gordura maior que a observada nos animais abatidos com $20 \mathrm{~kg}$ de PV.
}

Palavras-chave: alometria, cabritos, crescimento de carcaça, gordura, músculo, rendimento comercial

\section{Introduction}

The goat breeding activity in Southwestern Brazil is characterized by dairy breeds, which are explored in intensive system due to the high production cost in this region, mainly because of the land value. In this system, where the economic objective is milk production, male goats that were born in the property are considered a problem and are usually slaughtered just after their birth.

Although this region has great potential for meat production using dairy goats, this activity has not been developed by producers due to the lack of studies about growth, carcass traits and production costs related to this specific activity. 
There is little information about dairy goat growth and relative changes in live weight ( $\mathrm{LW}$ ) components in relation to animal weight or empty body weight (EBW).

Several authors have affirmed that the increase in body weight and/or age improves the carcass dressing because of the higher muscle:bone proportion and the amount of fat. This concept is applicable to ruminants in general, but is necessary to consider that goats are characterized by the higher visceral fat accumulation when compared to other species (Morand-Fehr et al., 1985; Ribeiro, 1997; Mahgoub \& Lodge, 1998), and this difference is more accentuated in dairy goats than in native or meat breeds (Sainz, 1996). However, the ideal weight and/or age has not yet been established for goats. It must be emphasized that the beginning of puberty can change the meat organoleptic characteristics.

The increase in the search for light meat by consumers associated to goat characteristics for showing carcass and meat with lower fat accumulation are responsible for increasing in the value of these products, especially when they have quality characteristics such as softness and flavor that are pleasant to consumers' taste. Therefore, to define de ideal moment for slaughter is important to meet the consumers' requirements.

The knowledge about the relative growth of goats will allow defining the best moment for slaughtering, when carcass yield, proportion of more valorized meats cuts proportion, muscle:bone ratio, fat amount and other non-carcass components are in the best situation for producer and consumer. Moreover, it is necessary to consider that the objective of the producer is to obtain profit, and the carcass production cost and the best slaughtered point need to be evaluated. Thus, the objective of this study was to estimate the relative growth curve of the live weight components, carcass and commercial meat cuts in Saanen goats.

\section{Material and Methods}

The experiment was carried out in the Goat Breeding Center of the Agriculture and Veterinaty Sciences School (FCAV), Unesp, Jaboticabal, SP, Brazil. Forty Saanen goats around $5 \mathrm{~kg}$ of initial LW were used. Goats remained individually in suspended cages and were weighted every week. They were dehorned at the age of 2 weeks. During three days after birth, cow colostrum was offered 3 times per day ad libitum. After this period, they were fed with $1.5 \mathrm{~L}$ of cow milk 2 times per day, being weaned at the age of 50 days.
Solid diet was offered from 7 days of life on, being weighted the remaining diet for adjusting them for $15 \%$ per day. Animals were fed with ration composed of $46.9 \%$ of corn plant hay (Zea mays L.) and 53.1\% of concentrate, which was composed of $25.9 \%$ of ground corn, $19.3 \%$ of soybean meal, $4.3 \%$ of sugar cane molasses, $2.0 \%$ of mineral mix, $0.8 \%$ of soybean oil and $0.8 \%$ of limestone. Nutritional composition per kg of dry matter was: $16.5 \%$ of crude protein, 2.46 Mcal of metabolizable energy and $48.8 \%$ of neutral detergent fiber.

To obtain the corn plant hay, corn was harvested by silage machine when the grain was on the dough stage. After this procedure, it was dried in the sun for $72 \mathrm{~h}$, and then, grounded in a knife mill with 0.1 -cm mesh sieve and stored in nylon bags until the time of utilization, when it was mixed with the concentrate.

Animals were distributed into 5 groups and slaughtered at 5.0, 12.5, 20.0, 27.5 and $35.0 \mathrm{~kg}$ of average LW. Twentytwo non-castrated goats were used in the slaughter with minor weights, being seven with $5.0 \mathrm{~kg}$; six with $12.5 \mathrm{~kg}$ and nine with $20.0 \mathrm{~kg}$. For slaughter with 27.5 and $35.0 \mathrm{~kg}$ of LW, 18 castrated goats with $17 \mathrm{~kg}$ of average LW for were used in order to avoid the undesired aroma and taste provided by puberty (Sainz, 1996).

When reaching the slaughter weight, the animals were submitted to a 24-hour solid fast and a 16-hour liquid fast in order to estimate the fasting live weight (FLW). Slaughter was done by electric shock followed by bleeding. After slaughter, the gastrointestinal tract (GIT), urinary bladder, and gall bladder contents were removed for empty body weight $(\mathrm{EBW})$ determination through the equation $\mathrm{EBW}=$ FLW - (GIT + urinary bladder + gall bladder contents). The GIT components were weighted after empting and peritoneal fat removing. Head (separated in atlanto-occipital joint) and feet (separated in carpal-metacarpal and tarsalmetatarsal joint) were weighted together, conserving the skin that was recovering them. The rest of skin was weighted separately. After that, the non-carcass components were obtained.

Shortly after slaughter, the carcass was weighted (without kidney, kidney fat and diaphragm) for obtaining the hot carcass weight (HCW). One hour later, the carcass was stored inside a cold chamber at $4^{\circ} \mathrm{C}$ for 24 hours for obtaining the chilled carcass weight (CCW). The commercial yield $(\%)=\mathrm{CCW}^{*} 100 / \mathrm{FLW}$, and the biologic yield $(\%)=$ HCW*100/EBW were determined.

Carcasses were shared longitudinally, being the left side sectioned into seven anatomical parts or commercial cuts (Yáñez et al., 2007). 
The left leg of each animal was frozen at $-20^{\circ} \mathrm{C}$ and thawed for dissection and body composition determination. In the toilette, tarsus and extreme distal of tibia were removed by a proximal cut in medial and lateral malleoli of tibia and in the tuberosity of the heel. Tissues corresponding to insertion of abdominal muscle and pelvic fat were also removed. The legs were dissected into tissues according to method of Yáñez et al. (2007).

Tissues were weighted separately and the leg weight was reconstructed and used for the correspondent calculus, because water losses occurred during the dissection, which modified the tissues weight.

For relative growth determination, the allometric equation was used, which is based on the hypotheses that the development is more related to weight than time necessary for reaching this weight. The allometric equation used was proposed by Huxley in 1932 (Berg \& Butterfield, 1976): $\mathrm{Y}=\mathrm{a} \mathrm{X}^{\mathrm{b}}$, where: $\mathrm{Y}=$ parameter whose development is investigated, $\mathrm{X}=$ size of the reference (empty body weight or cut weight), "a" = fractional coefficient, which represents the $\mathrm{Y}$ value when $\mathrm{X}$ is equal to 1 ( $\mathrm{a}=$ interceptor), and does not have biologic value; and "b" = allometric coefficient used for measuring the development of an organ, tissue or part of them, in relation to the whole.

Data were analyzed through PROC NLIN of SAS (1999) and the initial values for "a" and "b" estimation were used in a linear model $(\log Y=\log a+b \log X)$. These estimations were used for obtaining the allometric equation by establishing the allometric coefficient of $\mathrm{LW}$, cuts or tissue components. When $b=1$, the growth is named isogonic, indicating that $\mathrm{Y}$ and $\mathrm{X}$ development rates are similar during the growth period considered. When $b \neq 1$, the growth is named heterogonic. In this case, it can be positive ( $b>1)$, for an organ with late development; or negative $(b<1)$, for an organ with precocious development.

For verifying the $\mathrm{b}=1$ hypothesis, the $t$ test was used, considering $5 \%$ of significance level through the following formula: calculated $t=(b-1) / s(b)$. The calculated $t$ was compared with tabled t with 35 degrees of freedom of residue.

For the evaluation of fed cost in relation to chilled carcass weight (in $\mathrm{kg}$ ), the ration cost based on prices from November 2001 was considered (A Nata do Leite, 2001). For hay cost calculation, $10 \%$ was added to the silage cost because of the higher storage cost and the necessity to grind the hay. Prices were considered based on dry matter (DM). Price of the milk used was paid to producer according to “A Nata do Leite" (2001).

For feed cost calculation, the amount of ration offered to animals during the experimental period was considered because of the high selectivity of goats that did not allow the reutilization of the remaining diet. In the case of milk, the effective consumption was considered because of the use of nursing bottles and the feeding frequency ( 2 times daily) that allowed reutilizing the remaining milk. Regression equation was used for analyzing the feed cost in function of CCW. For construction of the regression equation used for feed cost calculation in function of $\mathrm{kg}$ of produced carcass, it was considered that animals slaughtered at $5 \mathrm{~kg}$ of LW and $2.4 \mathrm{~kg}$ of CCW had feed cost equal to zero.

\section{Results and Discussion}

The slaughter of animals at $5 \mathrm{~kg}$ of $\mathrm{LW}$ was done for using as reference and due to the fact that the majority of dairy goat producers slaughter males just after their birth. The other slaughter weights were defined in function of the pre-established periods or the expectation of animals' weight gain, which were $12.5 \mathrm{~kg}$ for the weaning phase and $20 \mathrm{~kg}$ for the period just before starting puberty, which occurred around the age of 4 months (Ribeiro, 1997).

Puberty determines the beginning of physiological changes, characterized by hormones releasing, which produce substances that modify the qualitative goat meat traits and compromises its acceptation by consumer. For this reason, animals that could be slaughtered at 27.5 and $35.0 \mathrm{~kg}$ of $\mathrm{LW}$ were castrated because they could reach this weight older than 4 month of age. They were castrated at $17.0 \mathrm{~kg}$ of LW so that anterior development was similar to that of the other animals.

Thirty-five $\mathrm{kg}$ of LW (15 kg of carcass weight, approximately) was considered as the maximum weight in which higher daily weight gain could be explored. It is characteristic in young animals and responsible for the maintenance of carcass and meat quality. Moreover, larger carcasses, due to their size and higher fat content, can show problems during commercialization in consumer marked, which is characterized by light meat consumption.

Table 1 shows the equations used for relative growth estimation and the allometric coefficient (b), as well as its determination $\left(\mathrm{R}^{2}\right)$ and variation (VC) coefficients.

Berg \& Butterfield (1976) reported that the allometric equation allows describing quantitatively the part:whole ratio, which is important for reducing all the information to only one value, instead of non registering details. According to Wallace, cited by Osório et al. (1995), the use of this equation requires assuming that $X$ and $Y$ maintain the same relation among their development rates during the studied period. It does not happen when great weight amplitude is 
Table 1 - Allometric equations for relative growth estimation of leg tissues, commercial cuts and live weight (LW) components, in relation to leg weight (LegW) and to empty body weight (EBW), respectively

\begin{tabular}{|c|c|c|c|c|}
\hline Item & Equation & “b” & $\mathrm{R}^{2}(\%)$ & CV (\%) \\
\hline \multicolumn{5}{|l|}{ Tissue composition (kg) } \\
\hline Bone & $\mathrm{Y}=0.2040 \mathrm{LegW} 0.7420$ & $\mathrm{~b}<1$ & 99.5 & 7.91 \\
\hline Muscle & $\mathrm{Y}=0.6215$ LegW 1.0021 & $\mathrm{~b}=1$ & 99.8 & 5.56 \\
\hline Total fat & $\mathrm{Y}=0.0435$ LegW 1.7607 & $\mathrm{~b}>1$ & 97.1 & 21.48 \\
\hline Subcutaneous fat & $Y=0.0167$ LegW 2.1520 & $\mathrm{~b}>1$ & 96.7 & 24.03 \\
\hline Intermuscular fat & $\mathrm{Y}=0.0286$ LegW 1.3437 & $\mathrm{~b}>1$ & 94.3 & 28.90 \\
\hline \multicolumn{5}{|l|}{ Commercial cuts (kg) } \\
\hline Shoulder & $\mathrm{Y}=0.040322 \mathrm{EBW} 1.124393$ & $\mathrm{~b}=1$ & 99.6 & 7.68 \\
\hline Neck & $\mathrm{Y}=0.028774$ EBW 0.969779 & $\mathrm{~b}=1$ & 98.9 & 11.83 \\
\hline Brisket & $\mathrm{Y}=0.019297 \mathrm{EBW} 1.089953$ & $\mathrm{~b}>1$ & 99.4 & 9.17 \\
\hline 1 st and $5^{\text {th }}$ ribs & $\mathrm{Y}=0.015851$ EBW 1.021269 & $\mathrm{~b}=1$ & 99.0 & 11.58 \\
\hline 6 th and $13^{\text {th }}$ rips & $\mathrm{Y}=0.014078$ EBW 1.209905 & $\mathrm{~b}>1$ & 99.5 & 8.23 \\
\hline Chump & $\mathrm{Y}=0.022762 \mathrm{EBW} 1.085800$ & $\mathrm{~b}=1$ & 99.2 & 10.21 \\
\hline Leg & $\mathrm{Y}=0.067408 \mathrm{EBW} 1.076827$ & $\mathrm{~b}=1$ & 99.7 & 5.73 \\
\hline \multicolumn{5}{|l|}{ LW components (kg) } \\
\hline Chilled carcass & $\mathrm{Y}=0.418984$ EBW 1.080568 & $\mathrm{~b}=1$ & 99.8 & 5.31 \\
\hline Non carcass components & $\mathrm{Y}=0.550169 \mathrm{EBW} 0.927928$ & $\mathrm{~b}=1$ & 99.5 & 8.17 \\
\hline GIT & $\mathrm{Y}=0.114708$ EBW 0.900055 & $\mathrm{~b}=1$ & 98.5 & 13.83 \\
\hline Head and feet & $\mathrm{Y}=0.227375$ EBW 0.731673 & $\mathrm{~b}<1$ & 99.9 & 4.08 \\
\hline Skin & $\mathrm{Y}=0.130677$ EBW 0.749184 & $\mathrm{~b}<1$ & 99.5 & 7.39 \\
\hline
\end{tabular}

$\mathrm{CV}=$ coefficient of variation.

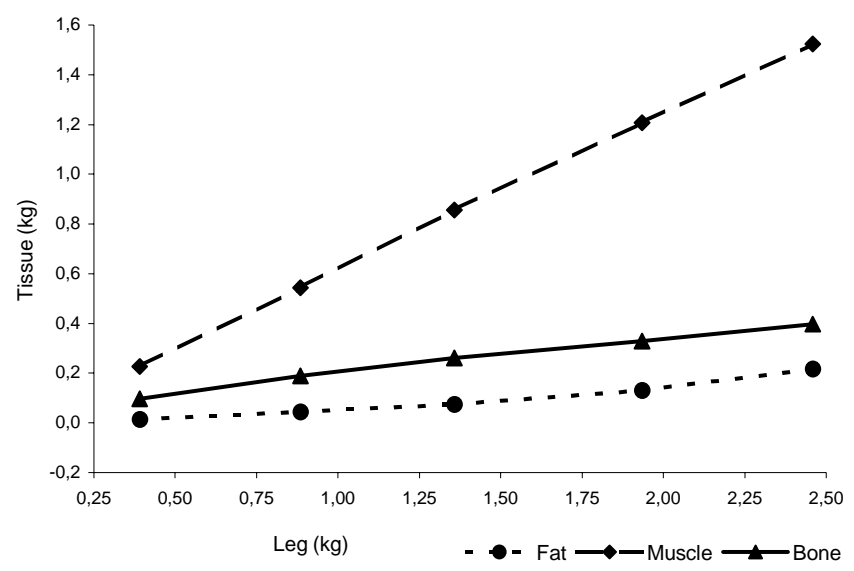

Figure 1 - Relative tissue growth in function of leg weight in goats weighting from 5 to $35 \mathrm{~kg}$ of live weight.

considered. These observations must be considered when the observed results are analyzed, as well as for comparisons with other works.

Leg tissues showed heterogonic coefficients, which were negative for bones $(b<1)$ and positive for fat $(b>1)$. The muscular tissue growth was isogonic $(b=1)$. Inter-muscular fat was deposited more precociously than subcutaneous fat, although both showed positive heterogonic coefficient. This leg tissue growth behavior agrees with the pattern accepted by the majority of authors who worked with complete dissection of carcasses from different species.
However, it disagrees with the hypothesis that leg could be used for characterization of whole carcass tissue composition.

In relation to leg, the precocious growth of osseous, late growth of adipose and similar growth of muscular tissues are in agreement with results obtained by Bueno et al. (1997) in Saanen goats; by Santos (1999) in ovine; and by Muldowwney et al. (1998) in bovine. However, these results differ from that observed by Roque et al. (1998a), who justified their results by the influence from different ovine genotypes used and by the high deviation pattern observed, which could have made the interpretation of their results difficult. Colomer-Rocher et al. (1992) observed the same tissue growth characteristics in whole carcass, but muscle showed growth rate $>1$ when leg was analyzed individually. Teixeira et al. (1995), working with Serrana goats around 6 to $22 \mathrm{~kg}$ of LW and 1.5 to 5 months-old, found isogonic growth for muscular and adipose tissue and negative heterogonic growth for osseous tissue.

The fact that inter-muscular fat showed more precocious growth than subcutaneous fat agrees with the majority of authors, but disagrees with Teixeira et al. (1995) who observed later growth for inter-muscular fat.

Leg tissue growth curves presented in Figure 1 show that muscle grew under a constant rate during all experimental period and that there was an increase in the growth rate of adipose tissue of $1.4 \mathrm{~kg}$ of leg weight (corresponding to $21 \mathrm{~kg}$ of LW) and a decrease in the muscle:fat ratio (from 
11.6:1 at $21 \mathrm{~kg}$ of $\mathrm{LW}$ to $7.0: 1$ at $35 \mathrm{~kg}$ of $\mathrm{LW}$ ). On the other hand, since from 0.9 to $2.5 \mathrm{~kg}$ of leg weight (12.5 to $35 \mathrm{~kg}$ of $\mathrm{LW}$ ) the bone growth rate starts to decrease and the muscle growth rate remains constant, it improved the carcass quality by changoffing the muscle:bone index, which increased from 2.8:1 to 3.8:1.

The improvement of the adipose tissue growth rate in $1.4 \mathrm{~kg}$ of leg weight coincides with the use of castrated animals and can be explained by the higher fat deposition observed in castrated males than in intact males, which was described by many authors as being a particular characteristic of this physiologic condition and independent of breed and species.

The relative growth of commercial meat cuts follows the EBW development, with exception of brisket and $1^{\text {st }}$ and $6^{\text {th }}$ rips, which showed positive heterogonic allometric coefficient (Table 1). These data disagree from that presented by Colomer-Rocher et al. (1992) and Teixeira et al. (1995) who observed allometric coefficient $<1$ for leg and shoulder cuts of goats. For Santa Inês and Bergamácia ovine, Santos (1999) observed negative heterogonic growth for leg and isogonic growth for shoulder. While Roque et al. (1998a) found an isogonic growth for both cuts in Corriedale and Rommey Marsh ovine.

Allometric coefficient of leg equal to 1 might be attributed to the dairy goat breed used in this study, characterized by poor posterior conformation and low subcutaneous fat deposition that allow the cut to follow the same behavior of muscular tissue, which is its main constituent. Loin, considered a region with later maturation, shows coefficient equal to 1 , indicating that its development follows that of the body (Table 1). These results coincide with that reported by Santos (1999) working with ovine, and differ from that shown by Teixeira et al. (1995), who observed later chump growth in Serrana goat.

Some of these differences can be attributed to the variation in weight of animals from this study. In Figure 2, is possible to observe that between 16.5 and $22.0 \mathrm{~kg}$ of EBW, a decrease in chump growth rate was observed, which could be caused by a re-direction of nutrients just after castration. These changes observed in the growth curve are not reflected by the allometric coefficient.

Sixth to $13^{\text {th }}$ ribs showed higher growth from $22 \mathrm{~kg}$ of EBW, evidencing its later maturity. Colomer-Rocher et al. (1992) evaluating ribs and chump together, found coefficient of $1.03(b>1)$, but data observed in this study indicated that ribs have a different behavior between their parts with a precocious growth in anterior part. It is possible that the later development of the posterior region

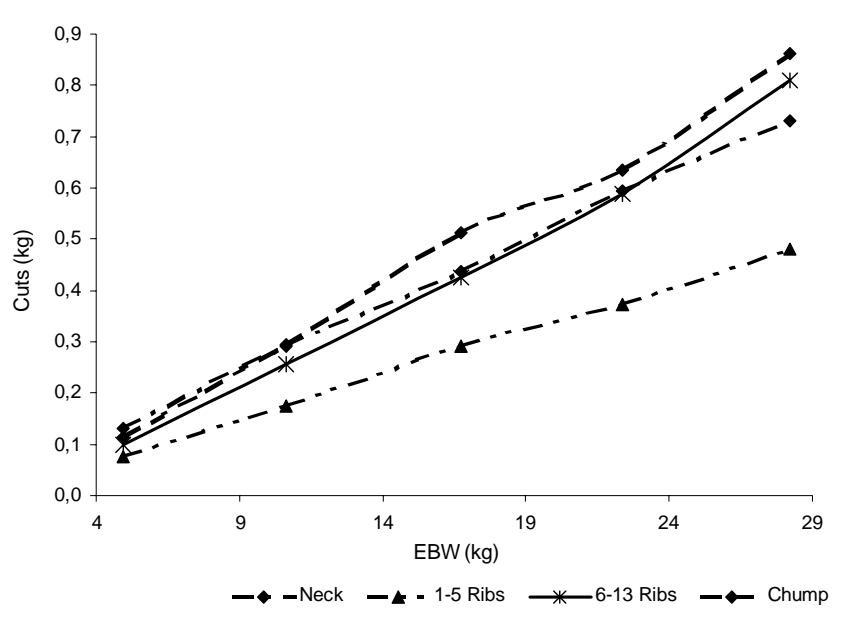

Figure 2 - Relative growth of cuts from neck, brisket, 1st to 5th ribs, 6th to 13th ribs and loin in function of empty body weight (EBW) in goat weighting from 5 to $35 \mathrm{~kg}$ of live weight.

of rib is caused by the higher subcutaneous fat deposition and lower muscle proportion in this region when compared to leg and chump cuts.

The neck growth curve showed a decrease in the growth rate between 22 and $28 \mathrm{~kg}$ of EBW (Figure 2). This curve behavior must have been influenced by animals' castration before puberty because in non-castrated animals, these cuts have higher participation than in female and castrated males and presents a positive heterogonic allometric coefficient (Colomer-Rocher et al., 1992). The higher development of male neck is a secondary sexual characteristic, being influenced by hormonal factors and usually observed in adult reproducers.

The relative growth of carcass and non-carcass components in relation to EBW shows allometric coefficient $\mathrm{b}=1$ (Table 1), following the body growth. It is not in line with other authors, who concluded that the increase in the weight:age ratio causes increase in the carcass proportion (Warmington \& Kirton, 1990). However, in Figure 3, it is possible to observe a constant increase in chilled carcass while non-carcass components showed a curve with a little superior accentuated inflection between 16.7 to $28.2 \mathrm{~kg}$ of $\mathrm{LW}$, which could cause an improvement in carcass dressing of animals with higher weight and, or age.

It is coincident with commercial and biological yield curves (Figure 4), which decreased when animals reached $21 \mathrm{~kg}$ of LW or $8.7 \mathrm{~kg}$ of CCW, and returned to the early values between 27.5 and $35.0 \mathrm{~kg}$ of LW. This yield curve behavior, more clearly visualized in the biological yield, is directly affected by the gastrointestinal (GIT) growth 


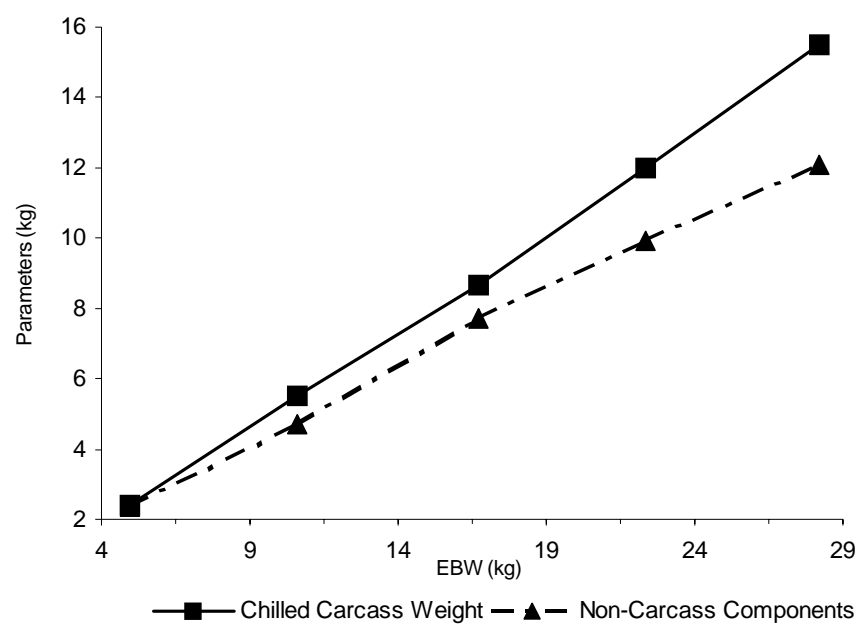

Figure 3 - Relative growth of chilled carcass (C. Carcass) and non-carcass component (Non-carcass) weights in function of empty body weight (EBW) in goats weighting from 5 to $35 \mathrm{~kg}$ of live weight.

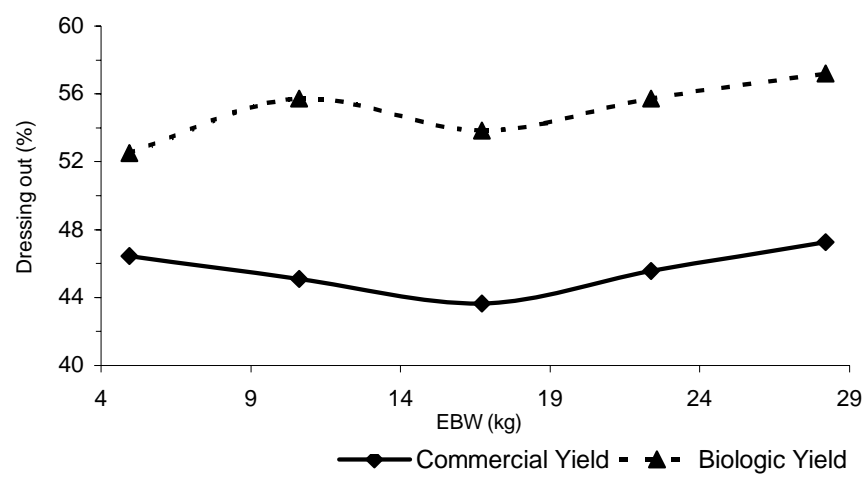

Figure 4 - Percentage of commercial yield (Chilled carcass weight/ fasting weight) and biologic yield (Hot carcass weight/ empty body weight) in function of empty body weight (EBW), in goats weighting from 5 to $35 \mathrm{~kg}$ of live weight.

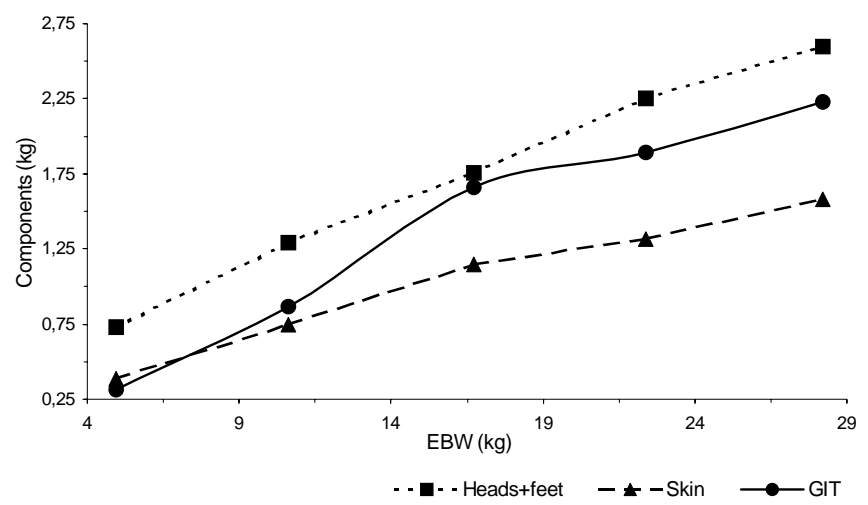

Figure 5 - Growth curve of head+feet, skin and empty gastrintestinal tract (GIT) in function of empty body weight (EBW), in goats weighting from 5 to $35 \mathrm{~kg}$ of live weight.
(Figure 5), which showed higher growth rate, between 5.0 to $21.0 \mathrm{~kg}$ of LW (particularly between 12.5 to $21.0 \mathrm{~kg}$ ), coinciding with period of higher pre-stomach development. The allometric coefficients were lower than 1 for skin and head plus feet; and equal to 1 for GIT (Table 1 ). The growth curves of non-carcass components were shown in Figure 5.

Bueno et al. (1997), working with Saanen goats between 8.3 and $28.0 \mathrm{~kg}$ of LW, observed linear increase of chilled carcass weight and linear decrease of head, viscera and feet proportion in function of the slaughter weight, without altering the participation of skin and digestive system, and concluded that the increase of age and, or weight produces improvement in the carcass yield. Roque et al.(1998b), working with ovine in grazing system and slaughtered with 7.5 months of age, obtained similar results such as the late development of carcass in Merino, Rommey Marsh and Texel breeds and the isogonic coefficient in Ideal and Corriedale breeds. Skin, viscera and feet showed isogonic growth in all genotypes analyzed, which have led researchers to conclude that the increase of LW causes an increase of carcass proportion and yield improvement. Warmington \& Kirton (1990) reported that some authors have observed that the increase of weight does not affect the carcass yield, but other authors obtained different results, yield improvements with increase of LW.

According to Boggs et al. (1998), the superior inflection of a typical sigmoid animal growth curve is determined by the beginning of the maturity period. This inflection was not observed for the variables studied, which could be associated to the typical adult weight of Saanen breed that, in this study, non-castrated goats reached around $21 \mathrm{~kg}$ of LW with three months of age; and castrated goats reached around $35 \mathrm{~kg}$ of LW with 5.5 months of age. It could be inferred that these animals did not reach sexual maturity. From the commercial point of view, it is important because the meat tenderness desired by consumers is influenced by animal maturity.

In comparisons between our results and those obtained by Teixeira et al. (1995), it is important to stress that besides differences attributed to breed characteristics (adult weight, fitness, etc), the animals used by these authors showed low daily weight gain (reaching $22 \mathrm{~kg}$ of LW at 5 months of age), isogonic allometric coefficient of adipose tissue, more precocious subcutaneous fat deposition when compared to inter-muscular tissue; following a growth pattern and fat deposition different from that observed in our study and in other works on the topic in goats (Morand-Fher et al., 1985; Colomer-Rocher et al., 1992; Mahgoub \& Lodge, 1996) and in ovine (Mahgoub \& Lodge, 1998; Roque et al., 1998a; Santos, 1999). 
Beside differences in the amount and type of deposited tissues, the growth rate also influences the production cost, in function of feed conversion and in relation to the time of permanence of animals in the property until commercialization. Thus, in addition to estimating the best moment for slaughter through carcass traits, it is important to consider the production cost of this carcass.

Due to fact that the main factor responsible by production cost is the feeding system, the entire cost can be estimated by feed cost per $\mathrm{kg}$ of carcass produced. Figure 6 shows the feed cost in function of CCW.

The cost for milk was $\mathrm{R} \$ 0.27$ per liter and for ration was $\mathrm{R} \$ 0.24$ per $\mathrm{kg}$. The cost of goats up to $5 \mathrm{~kg}$ of $\mathrm{LW}$ was not consider because it was included in the routine management cost for reproduction, being considered without value in this calculation. It has no applicability for goat producers but in this study, it was justified given the intention of verifying the effect of feed on cost of each additional $\mathrm{kg}$ of goat carcass produced instead of verifying the economic viability of the goat meat production.

It could be observed that the feed cost was higher up to $5.5 \mathrm{~kg}$ of carcass ( $\mathrm{R} \$ 4.44 / \mathrm{kg}$ ), corresponding to animals with $12.5 \mathrm{~kg}$ of $\mathrm{LW}$ during the suckling period. After this period, the feed cost decreased, being $\mathrm{R} \$ 3.39 / \mathrm{kg}$ between 5.5 and $8.7 \mathrm{~kg}$ of carcass. It was verified that the cost was maintained similar among the other slaughter weights. It seems that the higher milk cost affects the system cost. Thus, after the suckling period, the feed cost is lower. It is possible that the higher nutritional requirements of goats slaughtered at $21 \mathrm{~kg}$ of $\mathrm{LW}$ and the shorter period of time for dilution of the suckling cost can affect the

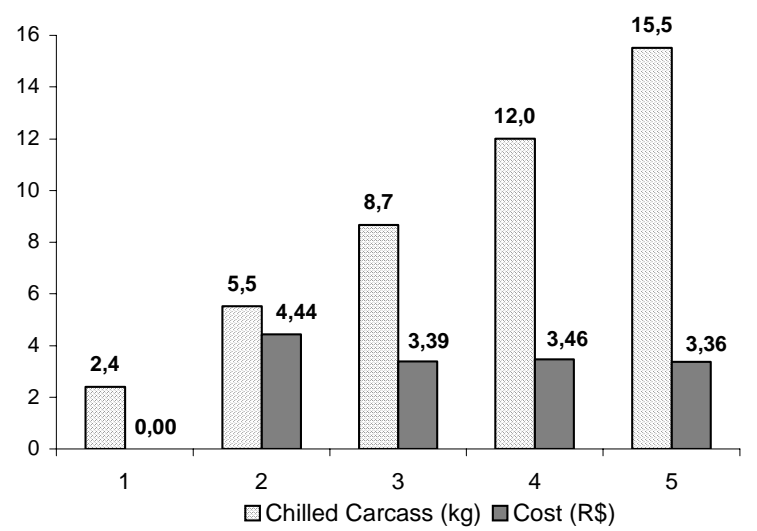

Figure 6 - Chilled carcass weight and feed cost per kg of chilled carcass of goats slaughted with 5.0, 12.5, 21.0, 27.5 and $35.0 \mathrm{~kg}$ of live weight (U\$S : R $\$$ relation $1.0: 2.80$ ). production cost of these animals. Goats slaughtered from 27.5 to $35.0 \mathrm{~kg}$ of LW, which were castrated and deposited higher amounts of fat (as seen in the growth curve), had a higher feed cost due to the high energetic cost of adipose tissue deposition.

With the high demand for lean meats and since from $27.5 \mathrm{~kg}$ of $\mathrm{LW}$, the growth rate of adipose tissue is higher than the decrease of osseous tissue proportion, it is estimated that after $35 \mathrm{~kg}$ of $\mathrm{LW}$, there is a low weight variation up to the carcass quality is negatively affected by the fat deposition.

Since the physiological maturation had not started in goats slaughtered at 5.5 months of age and 35.0 of LW, this slaughter age allows maintaining the tenderness trait of meat from young animals with moderated amounts of intermuscular fat, which improves the meat palatability and, consequently, allows the offer of a high-quality product.

The lack of pattern in goat meat and meat cuts classification is important to point out that the animal age, carcass weight, conformation and amount of fat will affect its approval by consumers and, consequently, its commercial price.

\section{Conclusions}

From the general knowledge about animal growth and the results obtained in this study about relative growth of LW components and commercial meat cuts, it was possible to confirm that Saanen goats with $15.5 \mathrm{~kg}$ of chilled carcass showed good carcass traits with acceptable yield for dairy goats and with a high participation of cuts with higher muscle proportion and commercial value. Non-castrated goats slaughtered at $21.0 \mathrm{~kg}$ of LW showed good carcass quality, meat cuts proportion and muscle:bone rate with a small fat proportion. Aiming to avoid the production of carcass with high adipose tissue proportion, castrated dairy goats raised in intensive system could be slaughtered at $35 \mathrm{~kg}$ of LW and 6 months of age, approximately. Animal commercialization will be economically viable when performed with $9 \mathrm{~kg}$ of carcass from non-castrated goats and with more than $12 \mathrm{~kg}$ of carcass from castrated goats.

\section{Literature Cited}

A NATA DO LEITE. Scott consultoria. Novembro, 2001. BERG, R.T.; BUTTERFIELD, R.M. New concept of cattle growth. Sidney: Sidney University Press, 1976. 240p.

BOGGS, D.L.; MERKEL, R.A.; DOUMIT, M.E. et al. Livestock and carcasses. An integrated approach to evaluation, grading and selection. 5.ed. Kendall: Hunt Publishing Company, 1998. 259p. 
BUENO, M.S.; SANTOS, L.E.; CUNHA, E.A. et al. Avaliação de carcaças de cabritos abatidos com diferentes pesos vivos. Boletín Indústria Animal, v.54, n.2, p.61-67, 1997.

COLOMER-ROCHER, F.C.; KIRTON, A.H.; MERCER, G.J. et al. Carcass composition of New Zealand Saanen goats slaughtered at different weights. Small Ruminant Research, v.7, p.161173, 1992.

MAHGOUB, O.; LODGE, G.A. Growth and body composition in meat production in Omani Batina goats. Small Ruminant Research, v.19, p.233-246, 1996.

MAHGOUB, O.; LODGE, G.A. A comparative study of growth, body composition and carcass tissue distribution in Omani sheep and goats. Journal of Agricultural Science v.131, p.329339, 1998.

MORAND-FEHR, P.; BAS, P.; ROUZEAU, A. et al. Development and characteristics of adipose deposits in male kids during growth from birth to weaning. Animal Production, v.41, p.349357, 1985.

MULDOWWNEY, D.; CONOLLY, J.; KEANE, M.G. Alternative statistical methods in the study of growth and body composition of animals. In: PROCEEDINGS OF THE BRITISH SOCIETY OF ANIMAL SCIENCE, 1998. Proceedings... s.l.: Society of Animal Science, 1998.

OSÓRIO, J.C.S.; SIEWERDT, F.; OSÓRIO, M.T.M. et al. Desenvolvimento alométrico das regiões corporais em ovinos Revista da Sociedade Brasileira de Zootecnia, v.24, n.2, p.326-336, 1995.

RIBEIRO, S.D.A. Caprinocultura: criação racional de caprinos. São Paulo: Nobel, 1997. 311p.

ROQUE, A.P.; OSÓRIO, J.C.S.; JARDIM, P.O. et al. Desenvolvimento relativo da composição regional e tecidual em cordeiros de cinco raças. In: REUNIÃO ANUAL DA SOCIEDADE BRASILEIRA DE ZOOTECNIA, 35., 1998, Botucatu. Anais... Botucatu: Sociedade Brasileira de Zootecnia. 1998a. p.627-629.

ROQUE, A.P.; OSÓRIO, J.C.S.; JARDIM, P.O. et al. Desenvolvimento relativo dos componentes do peso vivo em cordeiros de cinco raças. In: REUNIÃO ANUAL DA SOCIEDADE BRASILEIRA DE ZOOTECNIA, 35., 1998, Botucatu. Anais... Botucatu: Sociedade Brasileira de Zootecnia. 1998b. p.624-627.

SAINZ, R.D. Qualidade de carcaças de ovinos e caprinos. In: REUNIÃO ANUAL DA SOCIEDADE BRASILEIRA DE ZOOTECNIA, 33., 1996, Fortaleza. Anais... Fortaleza: Sociedade Brasileira de Zootecnia, 1996. p.3-14.

SANTOS, C.L. Estudo do desempenho, das características da carcaça e do crescimento alométrico de cordeiros das raças Santa Inês e Bergamácia. 1999. 143f. Dissertação (Mestrado en Zootecnia) - Universidade Federal de Lavras, Lavras, 1999.

STATISTICAL ANALYSIS SYTEM - SAS. User's guide. Cary: SAS Institute, 1999. v.8. (CD-ROM).

TEIXEIRA, A.; AZEVEDO, J.; DELFA, R. et al. Growth and development of Serrana kids from Montesinho Natural Park (NE of Portugal). Small Ruminant Research, v.16, p.263269, 1995.

WARMINGTON, B.G.; KIRTON, A.H. Genetic and non-genetic influences on growth and carcass traits of goats. Small Ruminant Research, v.3, p.147-165, 1990.

YÁÑEZ, E.A.; RESENDE, K.T.; FERREIRA, A.C.D. et al. Effects of feed restriction on yield, retail cuts and tissue composition of carcass of Saanen kids. Revista Brasileira de Zootecnia, v.36, n.3, p.666-673, 2007. 